\title{
PENGARUH MOTIVASI DIRI DAN PERSEPSI MENGENAI PROFESI AKUNTAN PUBLIK TERHADAP MINAT MENJADI AKUNTAN PUBLIK PADA MAHASISWA PRODI AKUNTANSI FAKULTAS EKONOMI UNIVERSITAS NEGERI YOGYAKARTA
}

\author{
Fajar Arifianto \\ Prodi Akuntansi Universitas Negeri Yogyakarta \\ fajarleonhart@gmail.com \\ Sukanti \\ Staf Pengajar Jurusan Pendidikan Akuntansi Universitas Negeri Yogyakarta
}

\begin{abstract}
Abstrak: Penelitian ini memiliki tiga tujuan utama. Pertama, untuk mengetahui pengaruh motivasi diri terhadap minat menjadi akuntan publik. Kedua, untuk mengetahui pengaruh persepsi mengenai profesi akuntan publik terhadap minat menjadi akuntan publik. Ketiga, untuk mengetahui pengaruh motivasi diri dan persepsi mengenai profesi akuntan publik terhadap minat menjadi akuntan publik pada mahasiswa Prodi Akuntansi FE UNY. Penelitian ini merupakan penelitian kuantitatif. Teknik pengumpulan data yang digunakan dalam penelitian ini adalah survei. Populasi dalam penelitian ini adalah mahasiswa Prodi Akuntansi angkatan 2010 dan 2011 FE UNY berjumlah 154 orang dengan proportionate stratified random sampling sebagai teknik pengambilan sampel diperoleh 112 sampel. Hasil pengujian H1 yang menyatakan motivasi diri berpengaruh positif terhadap minat menjadi akuntan publik pada mahasiswa Prodi Akuntansi FE UNY menunjukkan nilai signifikansi 0,000 $(<0,05)$, sehingga $\mathrm{H} 1$ terdukung secara statistik. Untuk $\mathrm{H} 2$ yang menyatakan persepsi mengenai profesi akuntan publik berpengaruh positif terhadap minat menjadi akuntan publik pada mahasiswa Prodi Akuntansi FE UNY menunjukkan nilai signifikansi 0,000 $(<0,05)$, sehingga $\mathrm{H} 2$ terdukung secara statistik. Untuk $\mathrm{H} 3$ motivasi diri dan persepsi mengenai profesi akuntan publik berpengaruh positif terhadap minat menjadi akuntan publik pada mahasiswa Prodi Akuntansi FE UNY menunjukkan nilai signifikansi $0,000(<0,05)$, sehingga $\mathrm{H} 3$ terdukung secara statistik dalam penelitian kali ini.
\end{abstract}

Kata Kunci: motivasi diri, persepsi mengenai profesi akuntan publik, minat menjadi akuntan publik

Abstract: This study has three main purposes . First, to know the influence of self-motivation to become a public accountant interest. Second, to know the influence of the perception about public accounting profession to become a public accountant interests. Third, to know the influence of self-motivation and perception about public accounting profession to become a public accountant interest in accounting students FE UNY. This research belong ts to quantitive research. Data collection techniques in this research was a survey. The population in this research is the accounting student class of 2010 and 2011, FE UNY amounted to 154 people with a proportionate stratified random sampling as a sampling technique obtained 112 samples. The test results of $H 1$ shows that self-motivation has positive influence on interest became public accountant at Accounting Student FE UNY showed a significance value of $0.000(<0.05)$, so that $\mathrm{H} 1$ is supported statistically. For H2 which states perception about public accounting profession has positive influence on interest became public accountant at Accounting Student FE UNY showed a significance value of 


\section{JURNAL NOMINAL / VOLUME III NOMOR 2 / TAHUN 2014}

0.000 ( $<0.05$ ), so H2 supported statistically. For H3 self-motivation and perception of the public accounting profession has a positive influence on interest became public accountant at Accounting Student FE UNY showed a significance value of 0.000 ( $<0.05$ ), so H3 is statistically supported statiscally.

Keyword: self-motivation, percepstion about public accountant profession, interest became public accountant.

\section{PENDAHULUAN}

Dalam era globalisasi seperti saat ini, semua negara dituntut untuk lebih berkembang. Termasuk juga Indonesia sebagai salah satu negara yang selalu mengikuti perkembangan zaman. Tentu saja hal tersebut berpengaruh dalam penyajian laporan keuangan. Dengan adanya kemajuan zaman seperti sekarang ini sudah pasti dituntut untuk meningkatkan akuntabilitas dantransparansi dalam setiap penyajian laporan keuangan dan hal ini merupakan bagian dari tanggungjawab akuntan publik. Akuntan Publik dapat dikatakan elemen penting untuk mewujudkan kehidupan masyarakat yang transparan, akuntabel dan perekonomian yang bebas dari kecurangan serta penipuan yang bersifat keuangan.

Praktik akuntansi di Indonesia sejatinya sudah ada sejak zaman kolonial. Dimana pada masa itu, profesi akuntan dipegang oleh akuntan Belanda dan beberapaakuntan Indonesia. Pendidikan tata buku juga telah diajarkan di sekolah-sekolah formal pada tingkat Sekolah Menengah. Namun profesi akuntan publik sendiri mulai berkembang pada tahun sekitar 1967, 1968 yaitu pada saat pemerintah mulai

mengeluarkan undang-undang tentang penanaman modal asing. Sejak saat itu profesi akuntan publik terus mengalami perkembangan hingga saat ini.

Secara umum, setelah melalui pendidikan S1, sarjana akuntansi mempunyai berbagai alternatif pilihan. Baik melanjutkan untuk mengikuti pendidikan profesi akuntansi atau melanjutkan jenjang akademik S2 maupun langsung berkecimpungdalam dunia kerja. Dalam dunia kerja sendiri, terdapat berbagai alternatif profesi yang dapat dijalankan oleh sarjana akuntansi, misalnya sebagai akuntan publik, akuntan pendidik, akuntan pemerintah atau akuntan perusahaan.

Wijayanti (2001) meneliti faktorfaktor yang mempengaruhi pilihan karir mahasiswa akuntansi. Penelitian tersebut dilakukan terhadap mahasiswa di Yogyakarta. Dari hasil penelitian diketahui bahwa dalam memilih suatu karir, mahasiswa mempertimbangkan mengenai finansial yang akan mereka terima, pelatihan profesional yang harus mereka jalankan, dan nilai-nilai sosial yang ada pada karir tersebut. 


\section{JURNAL NOMINAL / VOLUME III NOMOR 2 / TAHUN 2014}

Haris dan Djamhuri (2001) melakukan penelitian terhadap mahasiswa akuntansi Universitas Brawijaya dan Universitas Airlangga tentang faktor-faktor yang mendorong pemilihan karir bagi mahasiswa akuntansi, antara akuntan publik dengan non akuntan publik. Dari hasil penelitian tersebut diketahui terdapat lima faktor pertimbangan pemilihan profesi yaitu faktor ketersediaan kesempatan, nilai intrinsik pekerjaan, fleksibilitas kerja, persepsi mahasiswa tentang manfaat profesi akuntan publik, dan persepsi mahasiswa tentang pengorbanan profesi akuntan publik.

Dewasa ini, di Indonesia masih sangat kekurangan akuntan publik. Hal itu dapat disebabkan salah satunya karena kurangnya minat mahasiswa yang setelah lulus sarjana untuk berprofesi sebagai akuntan publik. Slameto (2010:180) menyatakan bahwa minat adalah suatu rasa lebih suka dan rasa ketertarikan pada suatu hal atau aktivitas, tanpa ada yang menyuruh. Dapat disimpulkan bahwa seseorang yang berminat terhadap suatu aktivitas akan memperhatikan aktivitas itu secara konsisten dengan rasa senang dikarenakan hal tersebut datang dari dalam diri seseorang yang didasarkan rasa suka dan tidak adanya paksaan dari pihak luar. Namun seperti yang diketahui minat berprofesi sebagai akuntan publik pada mahasiswa akuntansi UNY masih rendah.
Banyaknya persyaratan yang harus ditempuh bagi para mahasiswa sebelum ataupun sesudah menjadi akuntan publik juga menjadi penyebab kurangnya minat untuk menjadi akuntan publik. Namun akhir-akhir ini pemerintah bersama dengan IAPI (Institut Akuntan Publik Indonesia) berupaya untuk mengurangi persyaratanpersyaratan yang sekiranya memberatkan agar banyak dari lulusan mahasiswa nanti dapat memilih karir menjadi akuntan publik. Diantaranya yaitu direncanakannya ujian langsung sertifikasi untuk menjadi akuntan publik, sehingga bagi mahasiswa Akuntansi yang sudah lulus sarjana dapat langsung mengikuti ujian tersebut tanpa harus mengikuti pendidikan profesi akuntansi. Namun tentu saja persiapan yang dibutuhkan harus lebih ekstra dibanding yang sudah mengikuti pendidikan profesi akuntansi.

Selain itu terdapat faktor lain yang yang bisa mempengaruhi minat menjadi akuntan publik adalah motivasi dari mahasiswa itu sendiri. Menurut Sardiman (2005:89), Motivasi Diri adalah suatu motifmotif (daya penggerak) yang menjadi aktif dan berfungsinya tidak perlu dirangsang dari luar karena dari diri individu sudah terdapat dorongan untuk melakukan sesuatu. Motivasi Diri dapat juga disebut motivasi internal. Dalam kehidupan sehari-hari motivasi diri dibutuhkan karena dapat menyemangati diri seseorang untuk 


\section{JURNAL NOMINAL / VOLUME III NOMOR 2 / TAHUN 2014}

mencapai apa yang diinginkannya.

Seseorang yang mempunyai motivasi diri yang kuat akan sesuatu hal pasti cenderung akan berusaha semaksimal mungkin untuk mendapatkan hal tersebut.. Sehingga ia akan melakukan apapun untuk mencapai hal yang diinginkanya. Motivasi diri dapat digambarkan dengan kemauan untuk maju, kemampuan dalam mengambil inisiatif dan bertindak efektif, serta kemampuan dalam menghadapi kegagalan. Mahsiswa akuntansi yang memiliki motivasi diri yang kuat untuk menjadi akuntan publik, pasti akan selalu berusaha sebaik mungkin agar dapat mencapai keinginanya tersebut.

Selain itu persepsi seseorang akan suatu hal juga dapat mempengaruhi pemikiran orang tersebut. Dalam hal ini persepsi mahasiswa akuntansi mengenai profesi akuntan publik. Carol Wade dan Carol Tarvis (2007:194) berpendapat bahwa persepsi merupakan proses pengaturan dan penerjemahan informasi sensorik oleh otak. Persepsi dapat dikatakan merupakan salah satu aspek psikologis yang penting bagi manusia dalam merespon kehadiran berbagai aspek dan gejala di sekitarnya. Persepsi mengandung pengertian yang sangat luas, menyangkut intern dan ekstern.

Apabila seseorang mempunyai persepsi yang positif akan sesuatu hal, maka cenderung akan mendukung hal tersebut. Begitu pula sebaliknya apabila seseorang mempunyai persepsi yang negatif akan sesuatu hal maka cenderung untuk menghindari hal tersebut. Mahasiswa Akuntansi dalam mempersepsikan mengenai profesi akuntan publik bermacam-macam. Ada yang mempersepsikan mengenai akuntan publik itu positif maupun negatif sehingga secara tidak langsung dapat mempengaruhi keinginanya untuk berprofesi sebagai akuntan publik

Penelitian ini dilakukan untuk mengetahui pengaruh Motivasi Diri dan Persepsi Mengenai Profesi Akuntan Publik terhadap Minat Mahasiswa Prodi Akuntansi terutama di Fakultas Ekonomi UNY untuk berprofesi sebagai akuntan publik. Dalam penelitian sebelumnya menjelaskan bahwa motivasi berpengaruh terhadap minat mahasiswa akuntansi untuk berprofesi sebagai akuntan publik (Nurrahma Aria Rachman, 2012). Berdasarkan hasil wawancara yang dilakukan oleh peneliti pada sebagian mahasiswa, apabila diberikan pertanyaan mengenai minat menjadi akuntan publik, mereka masih menyatakan enggan untuk mengambil profesi tersebut. Penelitian ini dianggap perlu dilakukan karena dengan adanya motivasi karir dan persepsi mahasiswa akuntansi tentang profesi akuntan publik bagaimana nantinya dapat mempengaruhi langsung terhadap minat menjadi akuntan publik. 


\section{JURNAL NOMINAL / VOLUME III NOMOR 2 / TAHUN 2014}

\section{METODE PENELITIAN}

\section{Jenis Penelitian}

Penelitian ini merupakan penilitian kuantitatif dengan menggunakan metode kausal komparatif.

\section{Waktu dan Tempat Penelitian}

Penelitian ini dilakukan di Kampus Program Studi Akuntansi Fakultas Ekonomi Universitas Negeri Yogyakarta. Waktu Pelaksanaan Penelitian Januari-Februari 2014.

\section{Populasi dan Sampel Penelitian}

Populasi dalam penelitian ini adalah mahasiswa S1 Akuntansi Fakultas Ekonomi Universitas Negeri Yogyakarta. Universitas ini dipilih karena dianggap sebagai salah satu Universitas yang baik di Yogyakarta dan memiliki akreditasi baik. Selain itu, mahasiswa Universitas Negeri Yogyakarta telah mendapatkan atau sedang menempuh mata kuliah Auditing I dan 2 sehingga dianggap telah memahami apa itu profesi akuntan publik.

Data, Instrumen, dan Teknik Pengumpulan Data

Data yang diperoleh berupa jawaban responden atas kuesioner dari ketiga variabel dalam penelitin ini. Instrumen yang digunakan untuk mengumpulkan data berupa kuesioner dengan lima skala likert 1 sampai 4.
Berikut ini indikator yang digunakan untuk mengukur ketiga variabel dalam penelitin ini:

1. Motivasi Diri

Indikator untuk mengukur variabel Motivasi Diri menggunakan indikator pada instrumen Nugroho Cahyo Utomo (2011), yaitu:

a) Kemauan untuk maju

b) Kemampuan mengambil inisiatif dan bertindak efektif

c) Kemampuan dalam menghadapi kegagalan

2. Persepsi Mengenai Akuntan Publik.

Untuk mengukur variabel penekanan anggaran menggunakan indikator pada instrumen Adhi Surono Putro (2012), yaitu:

a) Nilai Intrinsik Pekerjaan

b) Gaji/Penghargaan Finansial

c) Pertimbangan Pasar Kerja

d) Kelebihan dan Kekurangan Profesi Akuntan Publik

\section{Minat Menjadi Akuntan Publik}

Indikator untuk mengukur variable Minat Menjadi Akuntan Publik menggunakan indikator pada instrument Adi Surono Putro (2012) yaitu :
a) Minat Pribadi
b) Minat Situasi
c) Minat Dalam Ciri Psikologis 


\section{JURNAL NOMINAL / VOLUME III NOMOR 2 / TAHUN 2014}

\section{Teknik Analisis Data}

Teknik analisis data yang dilakukan dalam penelitian ini adalah:

1. Statistik deskriptif untuk memberi gambaran terhadap objek yang diteliti melalui data sampel atau populasi (Sugiyono, 2010: 29) dan untuk melihat kecenderungan variabel.

2. Uji asumsi klasik yang terdiri atas beberapa pengujian, yaitu uji normalitas, uji heterokedastisitas, uji multikolinearitas, dan uji linearitas.

3. Uji hipotesis yaitu dengan regresi linear sederhana (untuk H1) dan uji nilai selisih mutlak (untuk $\mathrm{H} 2$ ).

\section{HASIL PENELITIAN DAN PEMBAHASAN}

Kuesioner yang terkumpul dalam penelitian ini berjumlah 112 kuesioner. Uji validitas dan reliabilitas menggunakan teknik sampel terpakai, sebanyak 30 responden. Ada beberapa item pernyataan yang tidak valid, sehingga harus dihapus dan tidak diikutsertakan dalam analisis selanjutnya. Ketiga variabel reliabel, karena menghasilkan nilai cronbach alpha>0,60. Setelah dilakukan uji asumsi klasik, diperoleh hasil bahwa data berdistribusi normal, tidak mengandung heterokedastisitas, tidak terjadi multikolinearitas, dan model regresi yang tepat adalah model linear, sehingga dapat dilakukan pengujian hipotesis.

\section{Hasil Penelitian}

Melalui statistik deskriptif, diperoleh kesimpulan bahwa variabel motivasi diri memiliki kecenderungan sedang dalam penelitian ini, untuk variabel persepsi mengenai profesi akuntan publik memiliki kecenderungan positif, sedangkan untuk variabel minat menjadi akuntan publik memiliki kecenderungan sedang

Pengujian $\mathrm{H} 1$ dengan uji regresi linear sederhana menghasilkan persamaan: Minat Menjadi Akuntan Publik = 4,269 + 0,494 Motivasi Diri

Dari hasil persamaan tersebut dapat dilihat bahwa pengaruh motivasi diri terhadap minat menjadi akuntan publik adalah positif atau $\mathrm{H} 1$ diterima.

Pengujian $\mathrm{H} 2$ dengan uji regresi linear sederhana menghasilkan persamaan: Minat Menjadi Akuntan Publik = 9,381 + 0,422 Persepsi Mengenai Profesi Akuntan Publik.

Dari hasil persamaan tersebut dapat dilihat bahwa pengaruh persepsi mengenai profesi akuntan publik terhadap minat menjadi akuntan publik adalah positif atau $\mathrm{H} 2$ diterima.

Pengujian H3 dengan uji regresi berganda menghasilkan persamaan:

Minat Menjadi Akuntan Publik = 3,949 + 0,476 Motivasi Diri + 0,284 Persepsi Mengenai Profesi Akuntan Publik

Dari hasil persamaan tersebut dapat dilihat bahwa pengaruh motivasi diri dan 


\section{JURNAL NOMINAL / VOLUME III NOMOR 2 / TAHUN 2014}

persepsi mengenai profesi akuntan publik secara bersama-sama terhadap minat menjadi akuntan publik adalah positif atau H3 diterima.

\section{Pembahasan}

Pengaruh Motivasi Diri Terhadap Minat Menjadi Akuntan Publik

Hasil penelitian mendukung hipotesis pertama yaitu variabel Motivasi Diri $\left(X_{1}\right)$ berpengaruh positif terhadap Minat Menjadi Akuntan Publik Pada Mahasiswa Prodi Akuntansi Fakultas Ekonomi Universitas Negeri Yogyakarta. Hal ini ditunjukkan oleh nilai koefisien regresi $X_{1}$ sebesar 0,721 menyatakan bahwa setiap kenaikan Motivasi Diri sebesar 1 poin akan meningkatkan Minat Menjadi Akuntan Publik sebesar 0,721 poin. Nilai probabilitas yang lebih kecil dari 5\% yaitu $0,000<0,05$ mengindikasikan bahwa Motivasi Diri berpengaruh positif terhadap Minat Menjadi Akuntan Publik.

Hasil penelitian ini konsisten dengan hasil penelitian yang dilakukan oleh Nugroho Cahyo Utomo (2011) yang menyatakan bahwa Motivasi Diri memiliki pengaruh yang signifikan terhadap Minat Menjadi Akuntan Publik. Motivasi Diri merupakan dorongan dari dalam diri untuk melakukan sesuatu yang diinginkan. Orang yang memiliki Motivasi Diri berarti orang tersebut memiliki kemauan dari dalam diri untuk maju dalam pencapaian tujuan tertentu. Kemauan tersebut muncul dari dalam diri orang tersebut dan akan melakukan hal-hal yang berkaitan dengan ketercapaianya tujuan yang ingin dicapainya.

Motivasi Diri ditandai dengan adanya, kemauan diri, kemampuan untuk mengambil tindakan inisiatif dan efisien, serta kemampuan menghadapi kegagalan. Sehingga akan mempengaruhi seberapa besar nantinya dalam keinginan Mahasiswa untuk menjadi akuntan publik.

\section{Pengaruh Persepsi Mengenai Profesi Akuntan Publik Terhadap Minat Menjadi Akuntan Publik}

Hasil penelitian mendukung hipotesis kedua variabel Persepsi Mengenai Profesi Akuntan Publik $\left(X_{2}\right)$ berpengaruh positif terhadap Minat Menjadi Akuntan Publik Pada Mahasiswa Prodi Akuntansi Fakultas Ekonomi Universitas Negeri Yogyakarta. Hal ini ditunjukkan oleh nilai koefisien regresi $X_{2}$ sebesar 0,422 menyatakan bahwa setiap kenaikan Persepsi Mengenai Profesi Akuntan Publik sebesar 1 poin akan meningkatkan Minat Menjadi Akuntan Publik sebesar 0,422 poin. Nilai probabilitas yang lebih kecil dari 5\% yaitu $0,000<0,05$ mengindikasikan bahwa Persepsi Mengenai Profesi Akuntan Publik berpengaruh positif terhadap Minat Menjadi Akuntan Publik. 


\section{JURNAL NOMINAL / VOLUME III NOMOR 2 / TAHUN 2014}

Hasil penelitian ini konsisten dengan hasil penelitian yang dilakukan oleh Yulia Fridani Sri Susilowati(2010) yang menyatakan Persepsi Mengenai Profesi Akuntan Publik memiliki pengaruh yang signifikan terhadap Minat MenjadiAkuntan Publik.

Persepsi Mengenai Profesi Akuntan Publik terkait dengan pandangan seorang mahasiswa terhadap profesi akuntan publik itu sendiri. Persepsi dapat dikatakan merupakan tanggapan langsung dari sesuatu. Persepsi merupakan salah satu aspek psikologis yang penting dalam diri seseorang dalam merespon kehadiran berbagai aspek dan gejala di sekitarnya.Setiap orang mempunyai kecenderungan dalam melihat benda yang sama dengan cara yang berbeda.Persepsi Mengenai Profesi Akuntan Publik dapat dilihat dari nilai intrinsik pekerjaan, gaji / penghargaan finansial, pertimbangan pasar kerja, dan Kelebihan dan Kelmahan Profesi Akuntan Publik. Seseorang dengan persepsi negatif terhadap sesuatu cenderung akan menolak sesuatu tersebut atau menjauh dari sesuatu itu. Namun apabila seseorang mempunyai persepsi positif terhadap sesuatu maka akan cenderung mendukung atau tertarik terhadap sesuatu tersebut.

Seorang mahasiswa akuntansi yang mempunyai Persepsi Mengenai Profesi Akuntan Publik yang baik pasti cenderung memiliki minat untuk menjadi akuntan publik. Dalam uraian di atas dapat disimpulkan bahwa Persepsi Mengenai Profesi Akuntan Publik mempunyai pengaruh terhadap minat menjadi akuntan publik.

\section{Pengaruh Motivasi Diri Dan Persepsi Mengenai Profesi Akuntan Publik Terhadap Minat Menjadi Akuntan Publik}

Hasil penelitian mendukung hipotesis keempat bahwa variabel Motivasi Diri dan Persepsi Mengenai Profesi Akuntan Publik berpengaruh positif secara bersamasama terhadap Minat Menjadi Akuntan Publik Pada Mahasiswa Prodi Akuntansi Fakultas Ekonomi Universitas Negeri Yogyakarta. Hal ini ditunjukkan oleh nilai $\mathrm{F}$ hitung sebesar 57,201 dan p value sebesar 0,000. Motivasi diri merupakan dorongan yang kuat dari dalam seorang individu untuk mencapai tujuanya. Sedangkan Persepsi Mengenai Profesi Akuntan Publik merupakan cara pandang seorang individu terhadap profesi akuntan publik

Seorang mahasiswa yang memiliki motivasi diri yang kuat dan mempunyai persepsi yang baik mengenai profesi akuntan publik maka cenderung akan berminat menjadi akuntan publik. Dari uraian diatas dapat disimpulkan bahwa Motivasi Diri dan Persepsi Mengenai Profesi Akuntan Publik berpengaruh terhadap Minat Menjadi Akuntan Publik. 


\section{JURNAL NOMINAL / VOLUME III NOMOR 2 / TAHUN 2014}

\section{SIMPULAN DAN SARAN}

\section{Simpulan}

Berdasarkan hasil penelitian seperti yang telah diuraikan sebelumnya dapat ditarik beberapa kesimpulan yaitu :

1. Motivasi Diri mempunyai pengaruh positif dan signifikan terhadap Minat Menjadi Akuntan Publik. Hal ini berarti apabila Motivasi Diri semakin kuat maka mengakibatkan Minat Menjadi Akuntan Publik semakin besar, begitu pula dengan Motivasi Diri yang rendah, maka Minat Menjadi Akuntan Publik juga menurun. Persamaan regresi hasil analisis regresi linier sederhana adalah $\mathrm{Y}=9,406+$ $0,721 X_{1}$. Hal ini ditunjukkan oleh nilai koefisien regresi $X_{1}$ sebesar 0,721 menyatakan bahwa setiap kenaikan Motivasi Diri sebesar 1 poin akan meningkatkan Minat Menjadi Akuntan Publik sebesar 0,721 poin. Nilai probabilitas yang lebih kecil dari 5\% yaitu $0,000<0,05$ mengindikasikan bahwa Motivasi Diri berpengaruh positif dan signifikan terhadap Minat Menjadi Akuntan Publik Pada Mahasiswa Prodi Akuntansi Fakultas Ekonomi Universitas Negeri Yogyakarta

2. Persepsi Mengenai Profesi Akuntan Publik mempunyai pengaruh positif dan signifikan terhadap Minat Menjadi Akuntan Publik. Hal ini berarti apabila Persepsi Mengenai Akuntansi semakin baik maka mengakibatkan Minat Menjadi
Akuntan Publik semakin besar, begitu pula dengan Persepsi Mengenai Akuntan Pulik yang rendah, maka Minat Menjadi Akuntan Publik juga menurun. Persamaan regresi hasil analisis regresi linier sederhana adalah $\mathrm{Y}=9,381+$ $0,422 \mathrm{X}_{2}$. Hal ini ditunjukkan oleh nilai koefisien regresi $X_{1}$ sebesar 0,422 menyatakan bahwa setiap kenaikan Persepsi Mengenai Profesi Akuntan Publik sebesar 1 poin akan meningkatkan Minat Menjadi Akuntan Publik sebesar 0,422 poin. Nilai probabilitas yang lebih kecil dari $5 \%$ yaitu $0,000<0,05$ mengindikasikan bahwa Persepsi Mengenai Profesi Akuntan Publik berpengaruh positif dan signifikan terhadap Minat Menjadi Akuntan Publik pada mahasiswa Prodi Akuntansi Fakultas Ekonomi Universitas Negeri Yogyakarta

3. Motivasi Diri dan Persepsi Mengenai Profesi Akuntan Publik secara bersamasama berpengaruh positif dan signifikan terhadap Minat Menjadi Akuntan Publik. Persamaan regresi hasil analisis regresi linier berganda adalah $\mathrm{Y}=3,949+$ $0,476 X_{1}+0,284 X_{2}$. Hal ini menunjukkan semakin baik Motivasi Diri dan Persepsi Mengenai Profesi Akuntan Publik maka Minat Menjadi Akuntan Publik pada mahasiswa Prodi Akuntansi Fakultas Ekonomi Universitas Negeri Yogyakarta juga semakin besar. Hal ini ditunjukkan 
JURNAL NOMINAL / VOLUME III NOMOR 2 / TAHUN 2014

oleh nilai $\mathrm{F}$ hitung sebesar 57,201 dan $\mathrm{p}$

Skripsi.

Universitas

Negeri

value sebesar 0.000 .

\section{Saran}

Yogyakarta.

Agoes, Sukrisno dan Jan Hoesada. (2009).

Bunga Rampai Auditing.

1. Hasil penelitian ini Minat Menjadi Akuntan Publik hanya bisa dijelaskan sebesar $51,2 \%$ oleh kedua variabel bebas, untuk peneliti yang akan datang sebaiknya dapat menambah variabel lain, misalnya variabel pemahaman Pendidikan Profesi Akuntansi (PPAK), Motivasi Ekonomi, Motivasi Karir, dan lain sebagainya.

2. Motivasi Diri mahasiswa Akuntansi yang berkaitan dengan berani menerima kegagalan perlu ditingkatkan agar kedepanya mental pada mahasiswa bisa semakin kuat. Bisa dengan melakukan hal-hal baru yang positif, menantang dan bermanfaat.

3. Persepsi mengenai profesi Mengenai Akuntan Publik pada mahasiswa Akuntansi cenderung ke arah positif sehingga perlu dipertahankan agar kedepanya banyak mahasiswa yang tertarik untuk berprofesi sebagai akuntan publik

\section{DAFTAR PUSTAKA}

Adi Surono Putro. (2012). "AnalisisFaktorFaktor Yang Mempengaruhi Minat Mahasiswa Akuntansi Untuk BerkarirMenjadi Akuntan Publik".

Jakarta:Salemba Empat.

Bhuono Agung Nugroho. (2005). Strategi Jitu Memilih Metode Statistik Penelitian Dengan SPSS. Yogyakarta : CV Andi Offset

Ellya Benny dan Yuskar. (2006). "Pengaruh Motivasi Terhadap MinatMahasiswa Akuntansi Untuk Mengikuti Pendidikan Profesi Akuntansi (ppak). Simposium Nasional Akuntansi 9. Padang.

Hasibuan, Malayu. (2003). Organisasi dan Motivasi Dasar Peningkatan

Produktivitas. Jakarta: Bumi Aksara

Haryadi Sarjono dan Winda Julianita. (2011). SPSS vs LISREL (Sebuah Pengantar, Aplikasi untuk Riset). Jakarta: Salemba Empat.

J.S Badudu (2003) Kamus Kata-kata Serapan Asing Dalam Bahasa Indonesia, Jakarta : Kompas.

Lutfi Harris dan AM Djamhuri.(2001). "Analisis Faktor-Faktor YangMelatarbelakangi Pemilihan Karir Bagi Mahasiswa Akuntansi: Antara Akuntan Publik Versus Non Akuntan Publik". Malang: Universitas Brawijaya, Jurnal Penelitian.vol. II, No 2, September. 


\section{JURNAL NOMINAL / VOLUME III NOMOR 2 / TAHUN 2014}

Mulyadi.(2002).AUDITING. Edisi $\quad \mathrm{Ke}$

Enam, PT. Salemba Empat Patria, Jakarta

Mulyati. (2004). Psikologi Belajar.

Yogyakarta: Andi Publisher

Nawawi, Hadar. (2003). Manajemen

Sumber Daya Manusia untuk Bisnis yang Kompetetif. Gajah Mada University Press, Yogyakarta

Nugroho Cahyo Utomo. (2011). "Pengaruh

Motivasi Diri dan Pengetahuan tentang profesi akuntan Publik terhadap minat untuk berprofesi menjadi akuntan publik pada mahasiswa progam studi akuntansi universitas negeri Yogyakarta”. Skripsi. FISE UNY

Pintrinch and Schunk. (1996). "Hand book of Counseling Psycology". Jurnal Penelitian. Hal.: 46- 62.

Sardiman. (2005).Interaksi Dan Motifasi Belajar Mengajar. Jakarta : Raja Grafindo Persada.

Shaleh, Abdul Rahman \& Wahab, Muhbib Abdul. (2004). Psikologi Suatu Pengantar Dalam Persfektif Islam. Jakarta: Kencana.

Silvia Opiyana. (2012). "Pengaruh Motivasi Terhadap Minat Mahasiswa Akuntan S1 untuk mengikuti Pendidikan Profesi Akuntansi (PPA) (Studi Pada Perguruan Tinggi Cirebon)". Skripsi. Universitas Muhammadiyah Purwokerto.
Slameto. (2010). Belajar dan Faktor-Faktor yang Mempengaruhinya. Jakarta : PT. Rineka Cipta.

Sugihartono, dkk.(2007). Psikologi Pendidikan. Yogyakarta: UNY PRESS.

Sugiyono. (2010). Metode Penelitian Bisnis. Bandung.: Alfabeta. ..(2012). Metode Penelitian Kuantitatif, Kualitatif, Dan $R \& D$.Bandung : Alfabeta. .(2012). Statistika Untuk

Penelitian. Bandung : Alfabeta.

Sunaryo. (2004). Psikologi untuk Keperawatan. Jakarta: EGC.

Wade, Carole dan Carol Tavris.(2007). Psikologi. Jakarta: Erlangga.

Walgito, Bimo. (2002). Pengantar Psikologi Umum. Yogyakarta : CV Andi Offset. Widyastuti, Widyawati,dkk dan Juliana. 2004. "Pengaruh Motivasi Terhadap Minat Mahasiswa Akuntansi Untuk Mengikuti Pendidikan Profesi Akuntansi”.Simposium Nasional Akuntansi VII.

Wijayanti, (2001). "Faktor-Faktor yang Mempengaruhi Pilihan

KarirMahasiswaAkuntansi”. Tesis. Universitas Gadjah Mada.

Yulia Fridani Sri Susilowati, (2010).’Pengaruh Persepsi dan Minat Mahasiswa Akuntansi mengenai Profesi Akuntan Publik terhadap Pilihan Kariernya sebagai Akuntan 
JURNAL NOMINAL / VOLUME III NOMOR 2 / TAHUN 2014

Publik pada Mahasiswa Jurusan

Akuntansi Universitas Negeri

Semarang”. Skripsi. Universitas

Negeri Semarang.

Teori Minat dan Motivasi. Diambil

darihttp://cosynook.wordpress.com/20

13/02/14/teori-minat/, diakses pada

tanggal 20 November 2013.

Tentang Profesi Akuntan Publik dan Etika

Profesi Akuntan Publik

http://pecintahabibana.blogspot.com/2

011/10/etika-profesi-akuntan-publik-

dan.html, diakses pada tanggal 29

November 2013.

Tentang Uji Validitas dan

Reliabilitas.http://p4mristkippgrisda.w

ordpress.com/2011/05/10/uji-validitas-

dan-reliabilitas/, diakses tanggal 20

Desember 2013. 